\title{
The Reconstruction of Indonesia's Mangrove Diplomacy
}

\author{
Verdinand Robertua \\ Universitas Kristen Indonesia
}

\begin{abstract}
Indonesia has the largest area of mangrove forests in the world, and Indonesia has the responsibility to protect mangrove forests as part of the global community in combatting greenhouse gas. However, it is still confusing the strategy in protecting Indonesia's mangrove forest. Mangrove forest in Indonesia has been degraded rapidly due to the government's plan changing the status of mangrove forest into commercial areas. Mangrove forest has significant economic value for the government and local community due to its location and woods. This research aimed to criticize the government's strategy in protecting mangrove by reconstructing Indonesia's mangrove diplomacy. The research method is case studies of mangrove rehabilitation in Jakarta and Bali. Primary data is obtained using directobservation in Pulau Tidung Kecil, Jakarta, and Bali's mangrove forest park. There is two conclusions in this article. Firstly, Indonesia's mangrove diplomacy has similar characteristics of Indonesia's environmental diplomacy. Secondly, this research concludes that the reconstruction of Indonesia's mangrove diplomacy needs more voice from local governments, eco-business and civil society.
\end{abstract}

Keywords: Mangrove forest, diplomacy, foreign policy, Indonesia

Indonesia memiliki hutan mangrove terluas di dunia dan Indonesia memiliki tanggung jawab untuk melindungi hutan mangrove sebagai bagian dari masyarakat dunia dalam mengatasi masalah gas rumah kaca. Permasalahan yang dihadapi adalah strategi perlindungan hutan mangrove Indonesia tidak jelas. Hutan mangrove Indonesia mengalami kerusakan sangat cepat akibat dari kebijakan Pemerintah Indonesia mengubah status hutan mangrove menjadi area komersial. Hutan mangrove memiliki nilai ekonomi yang strategis bagi masyarakat lokal dan pemerintah. Penelitian ini berusaha mengkritisi strategi pemerintah dalam melindungi hutan mangrove melalui rekonstruksi diplomasi mangrove Indonesia. Metode penelitian ini adalah metode studi kasus dengan mengambil studi rehabilitasi mangrove di Jakarta dan Bali. Data primer diperoleh dari observasi langsung di Pulau Tidung Kecil di Jakarta dan hutan mangrove di Bali. Penelitian ini memiliki dua kesimpulan. Pertama, diplomasi mangrove Indonesia memiliki karakteristik yang serupa dengan diplomasi lingkungan Indonesia. Kedua, peneliti berkesimpulan bahwa rekonstruksi diplomasi mangrove Indonesia perlu memerlukan peran lebih besar bagi pemerintahan lokal, bisnis hijau dan masyarakat sipil.

Kata-kata kunci: Hutan mangrove, diplomasi, kebijakan luar negeri, Indonesia 
Indonesian government now focus on rehabilitating mangrove ecosystem and protecting mangrove forest in many coastal areas. The government claimed that they had restored two thousand hectares of mangrove every year (MediaIndonesia. com 2019). Not only rehabilitation of mangrove ecosystems, but government has also punished corporations and individuals that have damaged mangrove forests for commercial purposes (Susanto 2019). With the combination of law enforcement and government budget, Minister of Environment and Forestry aimed to bring mangrove forests as the analytical instrument to mitigate the impact of climate change (Susanto 2019).

This article aimed to elaborate critically on government policy on mangrove forest rehabilitation and conservation in Indonesia. Similar to other essential ecosystems, mangrove forests faced the imminent threat of an increase in the speed of humanmade destruction (Murdiyarso et al. 2015). There is pressure from corporations to change the status of mangrove forests for commercial area due to its strategic location of mangrove forests. There are also many cases of overexploitation of mangrove for the shrimp, wood, and charcoal. The massive flow of plastic waste also threatened mangrove rehabilitation project (Kusmana 2017). It is claimed that the main factor of mangrove degradation is that the government prioritized the reclamation project that threatened mangrove area over mangrove conservation (Greenpeace 2018).

Mangrove can absorb carbon ten times bigger than land-based forest (Bird 2016). Mangrove is called one of the global's blue carbon (Bird 2016; UN Environment 2009). The success of mangrove protection is critical in handling the global climate emission, and it is the responsibility of states to protect and conserve mangrove. In order to help Indonesia addressing its environmental problems, many countries give technical and financial assistance to empower local public bodies and civil societies to protect and conserve Indonesia's environmental assets (Pramudianto 2008).

The degradation of Indonesia's mangrove has a potential negative impact on Indonesia's mangrove diplomacy. The problem with the environmental issue in foreign policy in developing countries is that the environmental concern is only aimed to attract foreign aid and technical cooperation projects (McBeath \& Wang 2008). In researching China's environmental diplomacy, McBeath and Wang (2008) argued that environmental diplomacy is designed to maximize international cooperation to benefit the reputation of a state in multilateral or bilateral negotiation. This research asked the effectiveness of Indonesia's mangrove diplomacy, specifically in linking with the local context. Nikijuluw (2016) has posited that the Indonesian government is not consistent in protecting mangrove. For example, a government-supported reclamation plan in Tanjung Benoa, Bali that threatened a vast area of the mangrove ecosystem.

The reconstruction of Indonesia's mangrove diplomacy started from a hypothesis that Indonesia's national interest mainly focused on improving national economic competitiveness without giving adequate emphasis on environmental sustainability. In this article, the domination of financial interest within Indonesia's foreign policy will be criticized using case studies in Bali and Jakarta.

\section{Indonesia's Mangrove and Global Climate Change Mitigation}

Indonesia has the largest mangrove area in the world, with around 3 million hectares 
(19\% of world mangrove) (FAO 2007). In 1999, Indonesia had 8,6 million hectares of mangrove (Gunawan et al. 2017, 659). The rate of deforestation in Indonesia's mangrove forest is alarming. The destruction of Indonesian mangroves is mainly caused by the expansion of the residential area, agriculture, fishponds, or recreational infrastructure (Kusmana 2014). It is a dilemma for the government because they have to provide jobs and welfare to the society and mangrove forest exploitation is an option for government.

In Bali, for example, the reclamation of Tanjung Benoa provoked intensive public debate. The government opined that the reclamation would create a new landmark that propelled local economic growth, attracted investment, and answered the property need. The government has issued Presidential Regulation number 51 the year 2014 to change the status of Tanjung Benoa from the conservation area to be agriculture area. However, environmental activists accused that the reclamation project will destroy a vast expanse of mangrove forest and the livelihood of local fishers. (Mongabay 2014) The expansion of palm oil plantation in the terrestrial area also provoked a similar debate (Kiara 2019). Murdiyarso (2015) also argued that the development of shrimp ponds had devastated the Indonesian mangrove forest. Indonesia is the top three biggest shrimp exporter. Mangrove conservation is then an essentially contested issue.

There is also a debate between economic development and environmental protection at the global level. United States of America (US) under the Donald Trump administration has decided to withdraw its membership from the Paris Agreement (Hynek 2009). Environmental protection is not in the top foreign policy agenda due to the threat of an economic downturn in the US economy. US' foreign policy aimed to secure jobs and prosperity amid Chinese' import in goods and services. Of course, environmentalists pointed out the imminent danger of climate change toward the US economy, such as a hurricane, extreme heat, or flood (The Washington Post 2017). The US is the biggest carbon emitter in the world (The Washington Post 2017).

Environmental diplomacy and mangrove diplomacy provide room for debate and contestation. In this regard, Indonesia's mangrove diplomacy and Indonesia's environmental diplomacy has a similar characteristic. Knowing environmental diplomacy and mangrove diplomacy as a contested issue, the author, wanted to transfer the dynamic of environmental diplomacy on mangrove diplomacy and the relevance of Indonesia's diplomacy in mangrove protection. As stated earlier, the government needs assistance from other governments to implements its responsibility in mangrove protection. An environmental diplomacy is then a tool for the government to gather support and aid for mangrove protection. Indonesia's environmental diplomacy needs to be detailed in an attempt to be a useful tool for gaining support and assistance in protecting mangrove and its ecosystem.

\section{Research Method}

This research is a qualitative analysis with an emphasis on researcher interpretation of primary and secondary data. The researcher collected primary data from observation in Pulau Tidung Kecil, Kepulauan Seribu, Jakarta, and Bali. In Pulau Tidung Kecil, the researcher also was involved in community service by planting mangrove and coral reef. In Bali, the researcher did field visits in Ngurah Rai Mangrove Forest, Denpasar, and 
Nusa Lembongan mangrove conservation, Klungkung Administration. The researcher talked with the local community around Nusa Lembongan dan Ngurah Rai and their local forestry office.

Based on the author's observation in Bali and Pulau Tidung Kecil, the author is eager to formulate Indonesian mangrove diplomacy. Primary and secondary data is critically analyzed to deconstruct and reconstruct a concept. It is possible because the researcher adopted interpretivist paradigm that emphasized contextual knowledge and understanding subjective experience (Porta and Keating 2008). Combined with the case-study method, the author analyzed the complexity of Indonesia's mangrove diplomacy from the case study of Bali and Pulau Tidung Kecil.

\section{Mangrove in Indonesia's Foreign Policy}

Many works of literature are highlighting the importance of mangrove and environmental issues in Indonesia's foreign policy. Firstly, Taufik formulated Indonesia's environmental diplomacy during Susilo Bambang Yudhoyono's leadership in 2004-2014 (Taufik 2016). According to her, Indonesia's environmental diplomacy is a tool for the government to gain a positive image in the multilateral negotiation but failed to bring direct benefit to the local people. Under Susilo Bambang Yudhoyono's administration, Indonesia was successful in gaining international aid in many environmental issues such as forestry, peatland, and mangrove.

Pramudianto (2008) introduced multi-track diplomacy in environmental issues. He mentioned that environmental diplomacy is not only the responsibility of the government but also private citizens, corporations, or mass media. Pramudianto quoted the definition of multi-track diplomacy of Diamond and McDonald (1996) and elaborated it into environmental issues and Indonesia's environmental diplomacy. According to Diamond and McDonald (1996), there is nine tracks of diplomacy; governments, professionals, business entities, private citizen, research units, an advocacy organization, religious bodies, funding, and mass media. Pramudianto mentioned the example of the university's role in Indonesia's environmental diplomacy by conducting diplomatic negotiation courses to students.

Establishing environmental diplomacy as a broad concept is not a simple task. Ali and Vladich (2016) stated that environmental diplomacy is a form of conflict resolution between environmental protection, economic development, and social justice. States, international organizations, and civil society need to deal with this conflict in the process of doing environmental diplomacy. A debate regarding responsibility between the North and the South is an example of the conflict between environmental protection and social justice at the global level (Benedick 1999).

Robertua and Sigalingging (2019) highlighted that there is pessimism from other countries toward the implementation of Indonesia's environmental diplomacy. The problem of north-south division, lack of coordination between the international organization, and domination of the profit sector hindered the effectiveness of Indonesia's environmental diplomacy. However, Robertua and Sigalingging (2019) argued that the implementation of the ASEAN Agreement on Transboundary Haze Pollution and the construction of the Peat Restoration Agency marked a new shift from the naming-and-shaming approach to consultation and dialogue in addressing 
transboundary environmental problems in Southeast Asia including forest fires.

Taufik's article is fruitful in looking at the importance of mangrove forests in Indonesia's foreign policy. Pramudianto's report emphasized the role of non-state in implementing Indonesia's environmental diplomacy. Ali and Vladich's article showed us that mangrove conservation is a contested issue because it involved conflicting interests around environmental protection, economic development, or social justice. Despite the pessimism on environmental diplomacy, Robertua and Sigalingging (2019) elaborated on a new government initiative in peatland and forest.

It is also vital to review government policy on mangrove conservation and rehabilitation. Indonesia is a member of the Paris Agreement and is obliged to reduce its carbon emission based on its nationally determined contribution (NDC). Indonesia promised to reduce $29 \%$ of its emissions in 2020 using its budget (UNFCCC 2016). If Indonesia received international support, Indonesia pledged to reduce $40 \%$ of its emissions. This foreign policy needs to be supported by domestic constituents. The most significant share of emission production comes from land-use (Wijaya et al. 2017). According to research led by Wijaya, forest deforestation and land/forest fires contributed significantly to land-based emission production.

The pessimism on the implementation of NDC is there. The author pointed out that there is two main problems regarding Indonesia's foreign policy on climate change. Firstly, a lack of coordination between ministries in the central government. Indonesia's diplomat needs to be equipped with detailed and precise information, but there is a lack of coordination between the Ministry of Foreign Affairs and the Ministry of Environment and Forestry. According to an informant in the Ministry of Environment and Forestry, diplomats in the Ministry of Foreign Affairs didn't have technical details on ongoing environmental problems at the local level.

Secondly, the author observed that the role of the local region in climate change is underestimated. The impact of decentralization in Indonesia is that local leaders (regent/governor) have more significant power in determining the activities/programs in their areas. Local leaders have the right to issue the permit to the corporation to manage concessions regarding mining resources, including coal and oil. When it comes to a conflict between mining interest and conservationism, local leaders tend to support business entities. There is also research showing local leaders accepted a bribe from mining companies to pay their campaign cost (Berenschot 2015).

In the case of mangrove conservation, the government of Indonesia has Presidential Regulation number 73 the year 2012 on the national strategy in mangrove ecosystem management. This regulation mandated central and local governments to design national and regional policies in mangrove ecosystem management. President, governor, and regent must set a team implementing the strategy. However, the law on forestry number 41 the year 1999 and the law on coastal areas and small islands number 1 the year 2014 mandated government to punish the corporation that changes the mangrove status illegally.

The problem with mangrove conservation is that there are different responses by the local government toward the implementation of Presidential Regulation number 73 the year 2012. As mentioned by Dharma (2019), Presidential Regulation number 73 the year 2012, is not implemented effectively in the Tanjung Pinang region in the province 
of Kepulauan Seribu. Tanjung Pinang has a vast area of mangrove forests around 1.300 hectares, and 100 hectares of them are damaged due to logging and the expansion of the residential regions (Dharma 2019). Meanwhile, Makassar city government in South Sulawesi implemented the regulation cooperating with Pertamina, Indonesia's stateowned companies and Eco natural, environmental non-governmental organization (Nawawi et al. 2019).

As stated in the research method, this research selects Jakarta and Bali as the case study to review the implementation of Presidential Regulation number 73 in the year 2012 in the context of Indonesia's environmental diplomacy. Jakarta and Bali are the centers of Indonesia's environmental diplomacy due to its strategic position as the capital city of Indonesia and the global tourism destination, respectively. Jakarta and Bali also have complex environmental problems, including air pollution, land sink, or the degradation of fishermen's livelihood. Mangrove conservation played a significant role in mitigating the impact of urbanization and industrialization in Jakarta and Bali.

\section{Mangrove Rehabilitation in Pulau Tidung Kecil, Kepulauan Seribu, Jakarta}

Jakarta is the capital city of Indonesia, and there are a lot of environmental problems in Jakarta. Air pollution, land sinking, and flood are significant environmental problems for the people of Jakarta. The new reclamation project in North Jakarta also degraded the livelihood of fishers. The reclamation project in Jakarta is a national issue because it involved national political elites and giant property corporations. Civil society and environmental groups have voiced their protest against the expansion of the existing reclamation land. During the war between fishers and corporations, a Jakarta parliament member becomes a suspect of corruption because he offered changes of regulation in exchange for financial compensation (Karim 2019).

Interestingly Jakarta has a vast area of mangrove forests in Pantai Indah Kapuk, Pluit, and Kepulauan Seribu. The government of Jakarta has allocated a significant budget for mangrove forest conservation in Pantai Indah Kapuk and mangrove rehabilitation in Kepulauan Seribu. It has become a popular hotspot for ecotourism in Jakarta. People can enjoy canoe and mangrove forests while planting new mangroves.

The mangrove habitat is not only in Pantai Indah Kapuk but also in Pulau Tidung Kecil in Kepulauan Seribu, Jakarta. The difference is that the mangrove forest does not exist in Pulau Tidung Kecil. Local people started to plant mangroves as a tool to mitigate the impact of abrasion (Paryono et al. 2018). The awareness of the threat of abrasion has motivated local people to allocate a particular area for mangrove rehabilitation. Mangrove rehabilitation is not only in Pulau Tidung Kecil but also in Pramuka Island. Haryanto (2013) has conducted research showing that Pramuka Island is fertile ground for mangrove plantation. There is yet research evaluating the effectiveness of mangrove rehabilitation in Pulau Tidung Kecil, but the author observed that mangrove had been planted and developed in Pulau Tidung Kecil.

The Jakarta government supports mangrove rehabilitation in Pulau Tidung Kecil through Pusat Budidaya dan Konservasi Laut (PBKL). Through Jakarta's assistance in the form of free seeds of mangrove, students or environmental activists can join mangrove planting in Pulau Tidung Kecil. However, the author observed that mangrove 
rehabilitation is not yet attracted attention from tourists. Tourists still focused on waterbased tourism, such as diving and snorkeling in Pulau Tidung Besar (Muhlisa 2015). If mangrove rehabilitation in Pulau Tidung Kecil is successful, it can be a tourism spot and a potential source of revenue for local people. Local peoples, PBKL, and university students, as well as private companies, have held mangrove planting in Pulau Tidung Kecil (Handayani 2019; UKI 2019). It is essential to formulate a policy on combining mangrove rehabilitation in Pulau Tidung Kecil with water-based tourism.

Concerning Indonesia's mangrove diplomacy, the development of mangrove rehabilitation in Pulau Tidung Kecil showed us that the awareness toward the importance of mangrove is more significant. Local initiatives in promoting mangrove in Pulau Tidung Kecil need support in terms of research and publication of research. The success of mangrove rehabilitation in Pulau Tidung Kecil will help local people combatting abrasion and Jakarta's problem of worsening air pollution. Jakarta is the capital city of Indonesia and still struggling with poor air quality due to the increasing number of cars and motorcycles.

Jakarta is the center of Indonesia's environmental diplomacy, and the support for mangrove rehabilitation in Pulau Tidung Kecil will determine the success of Indonesia's mangrove diplomacy. Mangrove conservation in Pantai Indah Kapuk should be a milestone for Indonesia in promoting mangrove rehabilitation in another part of Jakarta, including Pulau Tidung Kecil. Indonesia's mangrove diplomacy is a way to reorient the focus of Indonesia's mangrove diplomacy and to explore the hidden gems of Indonesia's mangrove resources, including mangrove rehabilitation in Pulau Tidung Kecil.

\section{Mangrove Conservation in Bali}

Bali has two popular areas of mangrove conservation; in Denpasar's Ngurah Rai Mangrove Forest and Nusa Lembongan, Klungkung Regency. Both of them have attracted a significant number of national and international tourists. In contrast with Pulau Tidung Kecil, the mangrove forest in Ngurah Rai and Nusa Lembongan have become the source of revenue for local peoples (Utami et al. 2018; Pemkab Klungkung 2012). Mangrove visit is a popular agenda for travelers because it offers affordable sightseeing, and it is combined with other tourism destinations such as snorkeling, diving, or travel. The popularity of mangrove forests as a tourism object in Nusa Lembongan dan Ngurah Rai is the example of Bali as second of Indonesia's environmental diplomacy.

However, Bali still has a complex environmental problem. There is an urgent problem of land reclamation that possible threatened the existence of mangrove forests in Nusa Lembongan and Ngurah Rai. The author observed that Nusa Lembongan and Ngurah Rai have a strategic location, and there are demands from corporations to change the status of mangrove forests into agricultural land and commercial area. It provoked a lot of resistance from civil society. The success of Bali as ecotourism and cultural tourism world destination created an impetus for large-scale expansion of hotels and supporting infrastructures and facilities. Without government support for environmental conservation, Bali will face more environmental problems such as abrasion, water crisis or air pollution. 
Bali's mangrove conservation marked a new question regarding Indonesia's foreign policy on climate change. Indonesia has received international support in mangrove conservation projects including in Ngurah Rai Mangrove Forest. Japan International Cooperation Agency (JICA) has poured assistance in the building information center, tracking roads, and watchtowers in Ngurah Rai Mangrove Forest (FPMB 2019; Embassy of Japan 2003). JICA is also involved in many mangrove conservation projects in Surabaya and Balikpapan through the plan of Mangrove Conservation and Sustainable Use in the ASEAN Region (Putra et al. 2019). Indonesia's partnership with Japan in protecting Bali's mangrove forest indicated Indonesia's foreign policy in attracting foreign assistance in conservation issues. Indonesia Foreign Ministry used mangrove diplomacy with Japan by engaging with the Indonesian Ministry of Forestry in ensuring the effectiveness of international support.

Tanjung Benoa's reclamation plan marked a new era in Indonesia's foreign policy in mangrove issues. Indonesia wanted to focus on economic growth, ensuring its status as an emerging economic power. The government has issued Presidential Regulation number 51 the year 2014, releasing some part of Bali's mangrove forest to become commercial area. Indonesia is now a member of G-20 and the biggest economy in Southeast Asia. Indonesia's President Joko Widodo set an ambition for Indonesia to be the global maritime fulcrum. As a global maritime fulcrum, Indonesia aimed to exploit the sea as resources for welfare, growth, and peace. However, this rhetoric masked a contradiction that economic expansion clashed with environmental interest. In the case of the Tanjung Benoa reclamation plan, the government didn't want to lose its opportunity to expand the Indonesian economy, sacrificing previous environmental cooperation projects with other countries.

Tanjung Benoa reclamation plan threatened the existence of the Ngurah Rai mangrove forest. It is not only an environmental problem for Bali but also other countries. Ngurah Rai mangrove forest is a popular tourist destination and solution for the worsening of Denpasar's air pollution. There is two possible scenarios for mangrove conservation in Bali; replacing mangrove forest with economical area or conserving existing mangrove forest. There are many local initiatives in defending the Ngurah Rai mangrove forest, but it will clash with the government and corporation's appetite in expanding the commercial area. The winner of this dispute will determine the future of Indonesia's environmental diplomacy.

\section{The Reconstruction of Indonesia's Mangrove Diplomacy}

Jakarta and Bali are two different provinces, but they shared a similar fate: a declining environmental livelihood. The problem of air pollution, water crisis, and land sink are considered as pressing issues for environmental activists. The question is then, on how International Relations scholars produced an adequate response to these problems. States are the most dominant analytical units in International Relations, and the focus is the interaction dynamic between countries. Concerning the environmental issue, states have different perceptions regarding the importance of the environmental problems in their national interest. However, global civil society in environmental issues has stronger power forcing states to be more serious addressing global environmental problems. 
This research argued that changes in economic power, environmental livelihood, or technological advancement influence the hierarchies of environmental issues in foreign policy. Growing awareness of the importance of mangrove and the threat of environmental deterioration reversed the domination of economic interest in Indonesia's foreign policy. Mangrove rehabilitation in Pulau Tidung Kecil showed that Jakarta peoples need mangrove forest in tackling air pollution and land sink. The mangrove forest in Denpasar is supported not only by residents but also by international actors. Indonesia's mangrove diplomacy is a way to re-focus Indonesia's foreign policy on the importance and the benefit of mangrove. Indonesia's foreign policy in climate change will be determined on the effectiveness of mangrove conservation and rehabilitation.

To achieve a useful Indonesia's foreign policy on climate change, Indonesia's mangrove diplomacy must be strengthened with support from local government, corporations, and civil society. Based on the case study in Pulau Tidung Kecil, Indonesia's mangrove diplomacy has a bright future because local government and civil society worked together to rehabilitate the mangrove ecosystem aligning with Presidential Regulation number 73 the year 2012. There are many new voluntary initiatives promoting ecotourism in Pulau Tidung Kecil with the focus of mangrove rehabilitation.

However, Bali faced a critical condition. The government of Indonesia has issued a decision to allow the corporation to use mangrove forests to become a new Bali's economic hub. The problem of coordination is real. In one side, the Ministry of Foreign Affairs and Ministry of Environment and Forestry wanted to implement Indonesia's commitment to protecting forest; however, President Yudhoyono released a decision to change the status of forest to be a commercial zone in 2014.

Based on the case of Bali, the President of Indonesia is an important actor in Indonesia's foreign policy in climate change. Indonesia's mangrove diplomacy could be vulnerable if the President supported projects and activities that harmed mangrove forests. The problem is on how to synchronize local issues with the dynamics at the national level. In the case of mangrove, the President can use Presidential Regulation number 73 the year 2012 to support mangrove movement or Presidential Regulation number 51 the year 2014 to prioritize economic growth over environmental protection. Mangrove conservation in Bali is critical because President Joko Widodo didn't cancel the previous regulation.

This research used the pyramid as the framework. At the bottom level, there is local government, corporation and civil society. In the middle level, there is President, and Indonesia's mangrove diplomacy is at the tip of the pyramid. There is three explanations derived from this pyramid. Firstly, inclusivity. Indonesia's foreign policy on climate change should be inclusive consisting of different parts and organizations. Indonesia's foreign policy would be more effective if it can mix more diverse elements into a systematic set of plans.

Secondly, this research emphasized the role of local government, corporation, and civil society by putting them in the bottom layer. Lastly, the dynamic of Indonesia's mangrove diplomacy is the most complicated part of the pyramid because it will combine different elements in the tomb. When the mangrove movement wanted to go to the upper level from the bottom, it will be more difficult because it has a deal with the President. When the mangrove movement wanted to go to high level from the 
President, it will be more difficult because it has to deal with other nations.

Mangrove in Indonesia's Foreign Policy

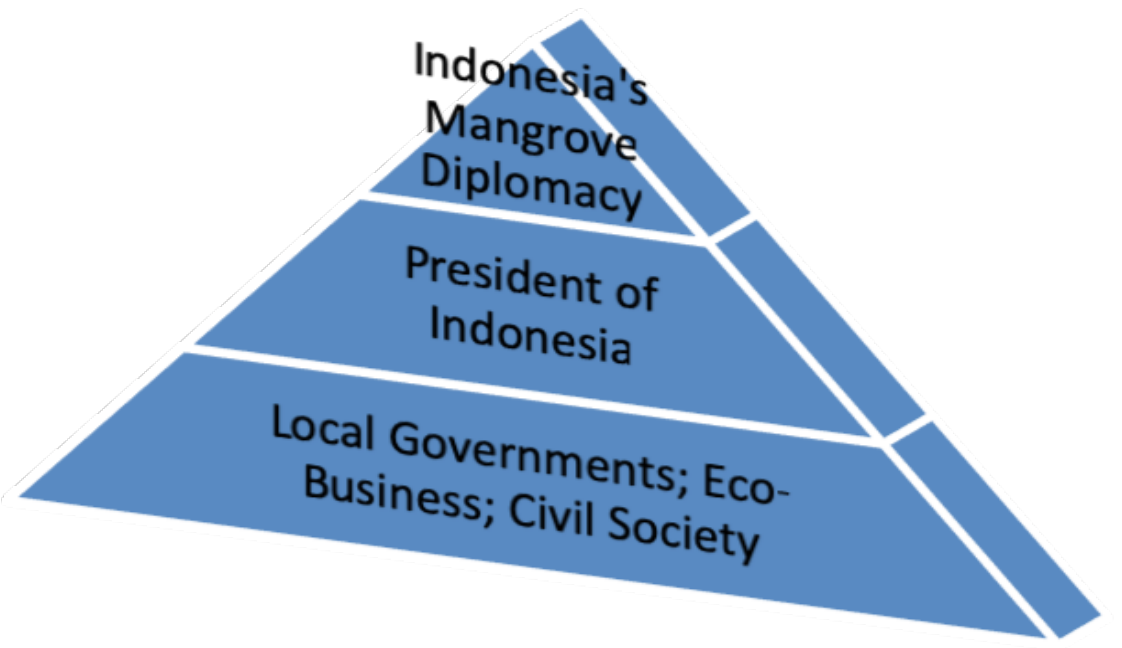

Source: composed by author

\section{Conclusion}

There are still many questions waiting to be discussed regarding Indonesia's mangrove diplomacy. The recent national movement in mangrove rehabilitation and conservation centered the question regarding mangrove in Joko Widodo's second term foreign policy. In line with this Indonesia has already adopted President Regulation number 73 the year 2012 on the national strategy of mangrove ecosystem management. Jokowi administration has also launched a national movement on mangrove care (Gewati 2019). There is a question further to review the effectiveness of Joko Widodo's mangrove diplomacy.

Tanjung Benoa reclamation plan in Bali pose a serious question for the current Indonesia's mangrove diplomacy. Based on the case of Tanjung Benoa, this article concluded that the President plays a pivotal role in the advancement of Indonesia's mangrove diplomacy. The growing awareness of civil society, corporation and local government in protecting mangrove in Jakarta showed that Indonesia's mangrove diplomacy might have a better future. This future can only be realized through the cooperation of actors in the pyramid structure of Indonesia Mangrove Foreign Policy. This cooperation is pivotal for the advancement of mangrove protection

The mix of different actors shapes Indonesia's foreign policy in mangrove issues as a pyramid. Indonesia's foreign policy has different layers and diverse influences. The form of intergovernmental cooperation and Indonesia's role in global cooperation in protecting mangrove should be revised further. 


\section{References}

\section{Books and Chapters in Books}

Ali, S., \& Vladich, H., 2016. "Environmental Diplomacy”. In C. Constantinou, P. Kerr, \& P. Sharp, 2016. The SAGE Handbook of Diplomacy. London: SAGE.

Benedick, R. E. 1999., "Diplomacy for the Environment". In A. I. Studies, 1999. Environmental Diplomacy. Washington: American Institute for Contemporary German Studies.

Diamond, L., \& McDonald, J., 1996. Multi-Track Diplomacy: A Systems Approach to Peace. Connecticut: Kumarian Press.

Haryanto, A., 2013. Efektivitas Rehabilitasi Mangrove di Pulau Pramuka, Kepulauan Seribu. Bogor: Institut Pertanian Bogor.

Hynek, N., 2009. Continuity and Change in the U.S Foreign and Security Policy with the Accession of President Obama. Prague: Institute of International Relations.

Kusmana, C., 2014. "Distribution and Current Status of Mangrove Forest in Indonesia”. In F. Hanum, A. L. Mohammad, K. R. Hakeem, \& M. Ozturk, 2014. Mangrove Ecosystems of Asia: Status, Challenges, and Management Strategies London: Springer.

Muhlisa, Q., 2015. Dampak Ekonomi dan Daya Dukung Kawasan Dalam Pengembangan Wisata Pulau Tidung, Kepulauan Seribu, DKI Jakarta. Bogor: Institut Pertanian Bogor.

Porta, D. D., \& Keating, M. 2008. Approaches and Methodologies in the Social Sciences A Pluralist Perspective. Cambridge: Cambridge University Press.

Wijaya, A. et al., 2017. How can Indonesia achieve its climate change mitigation goal? An analysis of potential emissions reductions from Energy and Land-Use Policies. Washington DC: World Resource Institute.

\section{Journal and Online Journal}

FAO (Food and Agriculture Organization), 2007. "The world's mangroves 1980-2005". Rome: FAO, FAO Forestry Paper, 153, p.77p..

Gunawan, H., et al., 2017. "Dynamics of Mangrove Community in Revegetation Area of Karangsong, North Coast of Indramayu District, West Java, Indonesia”. Biodiversitas Journal of Biological Diversity, 18(2), 659-665.

Kusmana, C., 2017. "Lesson Learned from Mangrove Rehabilitation Program in Indonesia”. Jurnal Pengelolaan Sumberdaya Alam dan Lingkungan, 89-97.

McBeath, J., \& Wang, B., 2008. "China's Environmental Diplomacy”. American Journal of Chinese Studies, 1-16.

Murdiyarso, D., et al., 2015. "The potential of Indonesian mangrove forests for global climate change mitigation”. Nature Climate Change, 1-4. 
Paryono, P. et al., 2018. "Pengembangan Destinasi Wisata Pulau Tidung; Communities Base Tourism”. Journal of Applied Business and Economics, 62-69.

Robertua, V., \& Sigalingging, L., 2019. "Indonesia Environmental Diplomacy Reformed: Case Studies of Greening ASEAN Way and Peat Restoration Agency". Andalas Journal of International Studies, 1-15.

Taufik, K. K., 2016. “Indonesia's Environmental Diplomacy under Yudhoyono: A Critical-Institutionalist- Constructivist Analysis". The Hague Journal of Diplomacy, 1-26.

Utami, N. D. et al., 2018. "Community Perception and Participation of Mangrove Ecosystem in Ngurah Rai Forest Park Bali, Indonesia”. Earth and Environmental Science (hal. 1-7). Bandung: IOP Conference Series.

\section{Online Article}

Berenschot, W., 2015. "Haze of Democracy". [Online] in http://www.insideindonesia. org/haze-of-democracy [accessed January 20 2016].

Bird, W., 2016. “Are 'Blue Carbon' Projects a Win for the Climate and the People?' [Online] in https://e360.yale.edu/features/african_mangroves_blue_carbon_ win_for_climate_and_for_people [accessed August 20 2019].

Dharma, M. G., 2019. "Implementasi Perpres RI Nomor 73 Tahun 2012 Tentang Strategi Nasional Pengelolaan Ekosistem Mangrove di Kota Tanjung Pinang”. [Online] in http://repository.umrah.ac.id/811/1/Jurnal\%20M\%20Guna\%20 Dharma.pdf [accessed August 27 2019].

Embassy of Japan, 2003. "Upacara Peresmian Gedung Pusat Informasi Mangrove" . [Online] dalam https://www.id.emb-japan.go.jp/newso3_18.html.

FPMB, 2019. "Working Area”. [Online] in http://fpmbali.org/en/about/workingarea .

Gewati, Mikhael, 2019. "Berpusat di Bunaken, OASE KK Inisiasi Gerakan Penanaman Mangrove di 12 Provinsi”. [Online] in https://regional.kompas.com/ $\mathrm{read} / 2019 / 07 / 06 / 22341531 /$ berpusat-di-bunaken-oase-kk-inisiasi-gerakanpenanaman-mangrove-di-12.

Greenpeace, 2018. "Pemberian Izin Lokasi Reklamasi di Teluk Benoa, Kebijakan Memunggungi Laut dan Tidak Peka Sosial-Lingkungan”. [Online] in https:// www.greenpeace.org/indonesia/siaran-pers/1139/pemberian-izin-lokasireklamasi-di-teluk-benoa-kebijakan-memunggungi-laut-dan-tidak-peka-sosiallingkungan/.

Handayani, Indah, 2019. "Jakarta Aquarium Tanam 673 Bibit Mangrove di Pulau Tidung”. [Online] dalam https://www.beritasatu.com/gaya-hidup/567040/ jakarta-aquarium-tanam-673-bibit-manrove-di-pulau-tidung.

Karim, M, 2019. "Pokok-Pokok Pikiran Reklamasi TelukJakarta dan Pengelolaan Pesisir dan Laut Indonesia”. [Online] in https://acch.kpk.go.id/images/ragam/makalah/ pdf/reklamasi/Pokok-pikiran-reklamasi-teluk-jakarta-dan-pengelolaan-pesisir- 
dan-laut-indonesia-muhamad-karim.pdf [accessed August 20 2019].

Kiara, 2019. "Hutan Mangrove Kian Susut Imbas Ekspansi Perkebunan Sawit". [Online] in http://www.kiara.or.id/2019/03/22/hutan-mangrove-kian-susutimbas-ekspansi-perkebunan-sawit/.

MediaIndonesia.com, 2019. "OASE-KK, KLHK Tanam 6o Ribu Pohon Lagi Pulihkan Fungsi Mangrove”. [Online] in https://mediaindonesia.com/read/detail/251796oase-kk-klhk-tanam-6o-ribu-pohon-lagi-pulihkan-fungsi-mangrove.

Mongabay, 2014. "Nasib Miris Hutan Mangrove Teluk Benoa. Accessed from Mongabay" [Online] in https://www.mongabay.co.id/2014/09/23/nasib-mirishutan-mangrove-teluk-benoa/.

Nawawi, Z. H., et al., 2019. "Peran Pemerintah dalam Pengelolaan Mangrove: Studi terhadap Pengelolaan di Lantebung”. [Online] in http://journal.uin-alauddin. ac.id/index.php/sls/article/download/4539/4147 [accessed August 27 2019].

Putra, P. G., et al., 2019. "Peranan JICA dalam Konservasi Mangrove di Indonesia Sebagai Bagian dari Program The Project For Mangrove Ecosystem Conservation And Sustainable Use in the ASEAN Region (MECS)". [Online] in https://ojs. unud.ac.id/index.php/hi/article/view/30064/18444 [accessed August 27 2019].

Susanto, Ichwan. 2019. "Mangrove Disiapkan Jadi Diplomasi Internasional Indonesia". [Online] in https://kompas.id/baca/humaniora/2019/o8/o7/mangrovedisiapkan-jadi-diplomasi-internasional-indonesia.

The Washington Post. 2017. "Trump's withdrawal from the Paris agreement means other countries will spend less to fight climate change". [Online] in https:// www.washingtonpost.com/news/monkey-cage/wp/2017/11/21/trumpsnoncooperation-threatens-climate-finance-under-the-paris-agreement/?utm _ term $=.14$ co42b2d8fa [accessed November 22 2017].

UKI. 2019. "Penanaman Mangrove dan Terumbu Karang oleh PALAMA FEB UKI”. Accessed from Universitas Kristen Indonesia: http://reporter.uki.ac.id/ penanaman-mangrove-dan-terumbu-karang-oleh-palama-fe-uki/.

\section{Others}

Pemkab Klungkung, 2012. Rencana Pengelolaan KKP Nusa Penida Kabupaten Klungkung, Provinsi Bali. Denpasar: Pemkab Klungkung.

UN Environment, 2009. Blue Carbon - The Role of Healthy Oceans in Binding Carbon. Nairobi: UNEP.

UNFCCC, 2016. First Nationally Determined Contribution Republic of Indonesia. Bonn: UNFCCC. 